\title{
«THE PALMER RAIDS» - REACTION TO «THE RED SCARE» AND EDGAR HOOVER'S ROLE IN THE ACTIONS OF THE U.S. DEPARTMENT OF JUSTICE
}

(C) 2019

Levin Yaroslav Aleksandrovich, candidate of historical sciences, junior researcher of World History, Law and Teaching Methods Department Samara State University of Social Sciences and Education (Samara, Russian Federation)

Abstract. The paper is devoted to reaction of the U.S. Department of Justice to the October revolution of 1917 in Russia and the process which received the name «The Red Scare» in the historiography. The basic changes which happened in Russia, the ideas of radical social justice, the dictatorship of the proletariat and the world revolution during the last stages of the World War I led to an extremely negative perception of the Bolshevik party and its policy in the USA. The general unfriendly spirit was warmed up by various publications accusing V.I. Lenin and his colleagues of communications with Germany (well-known Sisson's «documents») as well as by various publications in the press. At the same time, the revolution in Russia became an ideological beacon for anarchists and socialists worldwide including America. A special activity was shown by the galleanists organization (followers of the revolutionary and the ideologist of anarchism Luigi Galleani). From April to June 1919 they organized a series of explosions as well as attempts on the life of prominent politicians, businessmen and even the staff of intelligence agencies of the USA. In response to it the Attorney-General Alexander Mitchell Palmer initiated a series of military actions directed against all left-wing parties and groups in the country. The Bureau of investigations became the main body that was occupied in these actions. The paper analyzes the raids that were carried out by BI, their features and effects as well as the career of John Edgar Hoover, who was Palmer's personal assistant at that time and later became a director of FBI.

Keywords: USA; BI; FBI; J. Edgar Hoover; A. Mitchell Palmer; political investigation; galleanism; «The Palmer Raids»; 1919 United States anarchist bombings; General Intelligence Division; William J. Flynn; Anthony Kaminetti; «telegraph forms»; Bureau of immigration; Bufford.

УДК 908

DOI 10.24411/2309-4370-2019-13218

Статья поступила в редакцию 12.02.2019

\section{ПРОФЕССОР КУЙБЫШЕВСКОГО ПЛАНОВОГО ИНСТИТУТА ВАСИЛИЙ ЛЬВОВИЧ ПОГОДИН: МАТЕРИАЛЫ К БИОГРАФИИ}

(C) 2019

\author{
Жердева Юлия Александровна, кандидат исторических наук, \\ доцент кафедры институциональной экономики и экономической истории \\ Самарский государственный экономический университет (2. Самара, Российская Федерация)
}

Аннотация. В статье на основе архивных материалов о деятельности Куйбышевского планового института 1930-х годов реконструируется биография российского и советского дипломата, военного и ученого первой трети XX века Василия Львовича Погодина (1870 - после 1937). В ходе исследования был выявлен комплекс документальных свидетельств о дипломатической и педагогической карьере В.Л. Погодина в первые годы Советской власти, определены особенности его педагогической и партийной деятельности в Куйбышеве в 1933-1937 гг. Автор выделяет особую роль материалов партийного комитета планового института и профсоюза работников высшей школы в реконструкции биографии Погодина. Подчеркивается, что весь период преподавания в КПИ Погодин считался одним из лучших лекторов института и заслуживающим доверия партийным работником. Отмечается, что его дворянское происхождение, служба в царской армии и членство в партии эсеров вплоть до 1937 г. не были поводом для взысканий или преследования со стороны партии или администрации вуза. В результате автор приходит к выводу, что судьба Василия Львовича Погодина показывает неординарный характер его личности: сделав блестящую военную карьеру в годы поздней Российской империи и став генерал-майором Российской императорской армии, он сумел встроиться в новую советскую систему, кардинально поменяв сферу своей деятельности и добившись не менее выдающихся результатов в дипломатии и образовании, став полномочным представителем Дальневосточной Республики в Китае, директором ряда учебных и культурных учреждений Дальневосточного края, а затем профессором политэкономии Куйбышевского планового института.

Ключевые слова: Куйбышев; 1930-е гг.; экономика; экономическое образование; учебное заведение; плановый институт; марксизм; методика преподавания; Погодин Василий Львович; Погодин Александр Львович; дворянство; офицерство; Первая мировая война; история народного хозяйства; политэкономия; репрессии; партийные чистки.

В начале работы над биографией В.Л. Погодина в мае 2016 г. автору посчастливилось вступить в переписку с Людмилой Павловной Лаптевой (1926-2016) - историком, которому принадлежит заслуга создания первой биографии известного слависта Алек- сандра Львовича Погодина. Она написала тогда, что никогда не встречала имени Василия Львовича в немногочисленных документах его брата, сохранившихся в архивах Праги. Через несколько дней Людмилы Павловны не стало. Памяти Л.П. Лаптевой мы 
хотим посвятить это исследование, извлекшее из забвения жизнь одного из неординарных творцов российской истории - генерал-майора императорской армии, советского дипломата, педагога и экономиста Василия Львовича Погодина

В истории высшего экономического образования 1930-х годов до сих пор остается немало слабо изученных страниц. Причиной тому - изменение оптики взгляда ученых на исторические процессы того времени, смена методологических подходов к описанию истории сталинизма и советской индустриализации, а также уход на периферию исторических исследований прежней марксистской экономической дискуссии. Между тем 1930-е гг. в истории советской экономики и высшего образования являются важным периодом становления новой парадигмы, которую можно описать, используя инструментарий, предложенный Карлотой Перес [1]. В историческом контексте эта парадигма опирается на «Большую волну» смены технологий [2, с. 31]. Вслед за непрерывным ростом производства и усложнением машинных технологий в советской системе образования формируется новая описательная модель общественных отношений, столь же технократическая и инструментальная, как сами новые производственные технологии. Она опирается на марксизм, местами вульгарно понятый, и перекраивает всю систему советского образования под новый «производственный», технологический формат. С 1930 г. «индустриальным» в СССР становится практически любое высшее образование, от технического до педагогического. В экономическом образовании отражением этого «техницизма» стало появление плановых институтов. Даже сама специальность экономиста по классификатору профессий 1930 г. обозначалась как «экономистинженер» и была включена в группу инженернотехнических профессий [3, с. 124]

Возникновение плановых институтов в СССР пришлось на годы первой пятилетки и было призвано обслуживать интересы новых производственных комплексов как в промышленности, так и в сельском хозяйстве. Средневолжский (затем Куйбышевский) плановый институт (КПИ) возник в ноябре 1931 г. в период формирования вузов, включенных в систему Госплана СССР и готовивших специалистов для неё. Преподавательский коллектив первых лет планового института был немногочисленным: в 1934 г. в приказах по Средневолжскому планово-экономическому институту значатся 52 преподавателя, среди которых было лишь 5 профессоров [4, л. 22]. Специалистов с учеными степенями было еще меньше. Часть педагогического состава института пришла из стен бывшего коммерческого училища, Самарского университета или сельскохозяйственного института. Это были педагоги «старой закалки», хорошо известные в профессиональном сообществе города: Г.И. Баскин, Н.С. Аринушкин, А.А. Свешников, В.И. Шишлин, В.Д. Новоселов, Д.Е. Кравцов, В.В. Жуковский [5]. Особое место среди них принадлежит Василию Львовичу Погодину - профессору КПИ, судьба которого соединяет историю вуза с драматичными событиями в истории страны первых десятилетий XX века.

Немногочисленные сведения о биографии В.Л. Погодина, известные из разрозненных исторических исследований, могут уложиться в пару абзацев. До не- давнего времени была известна лишь первая половина его жизни - служба в Российской императорской армии, восстановленная по послужным спискам и документам о награждениях [6-8]. В данной статье впервые реконструируется вторая половина жизни В.Л. Погодина - деятельность его в годы Гражданской войны, а также в период его административной, преподавательской и научной работы в 1919-1937 гг.

Статья написана на обширном архивном материале, обнаруженном в фондах Центрального государственного архива Самарской области (ЦГАСО), Самарского областного государственного архива социально-политической истории (СОГАСПИ), архива Самарского государственного экономического университета (СГЭУ), архива Музея СГЭУ, Российского государственного архива социально-политической истории (РГАСПИ). Методология исследования опирается на принципы объективности и историзма в реконструировании биографии личности. Особое значение в исследовании имеет компаративистский анализ разных типов источниковых данных: текстов, автором которых являлся сам В.Л. Погодин (автобиография, заявления, статьи, выступления на заседаниях ученого совета и парткома), официальных документов (протоколы заседаний парткома и профсоюза), визуальных источников (фотографии В.Л. Погодина). Структура статьи последовательно раскрывает жизнь Погодина на фоне сложных исторических процессов, которые Россия переживала в первой трети XX в.: в первой части автор приводит краткие биографические сведения о В.Л. Погодине, опираясь на данные отечественной историографии; вторая часть является публикацией уникального документа - автобиографии Погодина, обнаруженной в фондах СОГАСПИ; в последней и самой обширной части исследования автор анализирует сведения автобиографии, опираясь на методы источникового анализа и визуальной истории. Такая структура работы, построенная от частного к общему, позволяет более детально и скрупулезно исследовать деятельность В.Л. Погодина и показать коллизии его жизни в широком историческом контексте.

Василий Львович Погодин родился 20 ноября 1870 г. и являлся старшим братом известного русского историка-слависта Александра Львовича Погодина (1872-1947), профессора Варшавского (18961906), Харьковского (1910-1920) и Белградского (1920-1944) университетов [9, с. 439]. Погодины происходили из дворян Казанской губернии, но, рано оставшись без отца, были стеснены в средствах, из-за чего старший из братьев избрал военную карьеру. После окончания Санкт-Петербургской гимназии в 1889 г. В.Л. Погодин поступил на военную службу, но изучение наук не бросил. Успешно закончив курс Московского пехотного юнкерского училища, продолжил обучение военным наукам в Александровской военно-юридической академии, по окончании которой в 1898 г. получил чин штабс-капитана. Был отмечен «за отличные успехи в науках». С 1899 г. находился на военно-судебной службе. В 1900 г. был переведен на Дальний Восток. Участвовал в военных кампаниях 1900-1901 гг. и 1904-1905 гг. Награжден орденами св. Станислава (2-й и 3-й ст.), св. Анны (2й и 3-й ст.) и св. Владимира (3-й и 4-й ст.), а также китайским орденом Двойного дракона (3-й ст.). В 
царской армии дослужился до чина генерал-майора (с 1915 г.), в годы Первой мировой войны был военным судьей Иркутского военно-окружного суда (1914-1916 гг.) [7]. С 1 октября 1918 г. был назначен и.о. начальника Военно-Судного отдела Военного ведомства Крымского Краевого правительства в г. Симферополь, а с 27 октября 1918 г. - членом Межведомственной комиссии по разработке положений о Крымском военно-окружном суде [8, с. 21].

Впоследствии признал Советскую власть и вернулся на Дальний Восток. С 1920 г. - член РКП(б) [10, л. 21]. Остался на военно-дипломатической службе, став в 1920-1922 гг. одним из видных деятелей Министерства иностранных дел Дальневосточной республики (ДВР) - буферного государства, призванного добиться дипломатического признания Советской власти Китаем и решить вопрос о КВЖД. В сентябре 1922 г. возглавлял Миссию иностранных дел ДВР в Пекине и вел переговоры об установлении политических и экономических отношений с Китаем $[11$, с. 20]. Весь состав миссии контролировался из Москвы лично В.И. Лениным. В марте 1923 г. участвовал в переговорах РСФСР с Китаем по поводу КВЖД [12, с. 85]. С окончанием дипломатической работы Погодин стал преподавателем. В 1929 1931 гг. являлся доцентом Государственного Дальневосточного университета (г. Владивосток), преподавал экономические дисциплины [13, с. 102]. После реорганизации университета был переведен в Хабаровск, где стал первым директором Дальневосточной краевой научной библиотеки, а также возглавил только что созданный Институт народного хозяйства [14]. С 1933 г. преподавал в Куйбышевском плановом институте - профессор по курсу истории народного хозяйства и истории экономических учений. Разработал проект новой методики ведения учебных занятий. В 1936 г. утвержден в звании профессора. В апреле-мае 1937 г. заведовал кафедрой политэкономии, одной из ведущих кафедр института. В 1937 г. во время «чисток» был уволен «за профнепригодность». О дальнейшей судьбе не известно.

Лишь благодаря сохранившейся в фондах СОГАСПИ автобиографии В.Л. Погодина, составленной 2 апреля 1936 г., удалось восстановить некоторые подробности его судьбы. Принимая во внимание скудость сведений о жизни обоих братьев Погодиных [15, с. 6], представляется важным привести этот документ целиком и в авторской орфографии.

«Автобиография

Родился в 1870 г. в г. Нижнем Новгороде. Дед крестьянин, получивший дворянство за поход 18121814 г2. Больше о нем ничего не сльимал и никогда его не видел. Отец мой - присяжный поверенный (адвокат), впоследствии юристконсульт. Родителей потерял я рано: мать - в детстве, отияа - в возрасте 16 лет. После смерти отиа жил на пенсии (17 р.) и частными уроками. В 1889 г. окончил 10-ю Петербургскую гимназию и, не имея средств для продолжения образования, поступил в военно-училищные курсы в Москве, которые кончил в 1891 г., после чего был назначен младиим офицером в 46 пех. Днепровский полк в г. Проскурове. В 1895 г., желая получить высшее образование, поступил в ВоенноЮридическую Академию, которую окончил в 1898 г.
После того служил по военно-судебному ведомству в Петербурге (1 год), в Одессе (1 год), во Владивостоке (1 год), в Иркутске (2 года), но преимущественно в Манчжурии (с 1901 по 1914 г.). В 1916 г. командирован на Румынский фронт, где состоял председателем Суда VI армии.

Февральскую революцию встретил в г. Болграде, в Бессарабии. В марте там же организовал совместно с несколькими земцами республиканский клуб и состоял его председателем до сентября 1917 г. Клуб был средоточием воспитательной работьл в массах армии, объективно содействуя их большевизации. В апреле 1917 г. примкнул к партии социалистов-револючионеров, соблазнившись её названием. Вскоре стал разочаровываться и начал работать против войны и против коалиции. Порвал с этой партией, когда выявилось ее отночение (враждебное) к Октябрьской революции, которую я рекомендовал партии приветствовать. В ноябре 1917 г. я заболел тяжелой формой воспаления легких и встал лишь в январе, когда Бессарабия была оккупирована Румынией. После ликвидации Суда в апреле 1918 г. я выехал в Одессу, в надежде пробраться в Иркутск, где оставил свою большую библиотеку и хорошее педагогическое имя, но за отсутствием сообщений остался в Одессе. Жил без работы на половину прогонных денег, выданных мне Одесским воинским начальником для возвращения в Сибирь (другую половину я должен был получить в Сибири). Не желая подчиняться режиму Скоропадского и в поисках работы, я выехал в октябре 1918 г. в Крым, где нашел работу сначала в качестве зав. военно-судебной частью при Временном Правительстве, а затем в Кассационном суде.

Узнав, что из Одессы отправляется пароход во Владивосток, я 5 апреля 1919 г. выехал в Одессу, но 6 апреля утром пароход был задержан на внешнем рейде, так как в Одессе был бой (вступила Красная Армия). Всех пассажиров пересадили на итальянский транспорт и отправили в Константинополь, а оттуда - на Принцевы Острова. Пробыв там месяия два под наблюдением франиузских агентов, я воспользовался отправкой во Владивосток парохода «Иерусалим», шедмего под франиузской командой. В конще сентября прибыл во Владивосток, а затем направился в Омск, чтобы получить вторую половину денег по демобилизации. Из Омска через несколько дней выехал в Иркутск, но попав в полосу эвакуации и бегства бельх из Омска, доехал до Новосибирска в начале декабря и остался ждать вступления Красной Армии. 14 декабря 5-я Красная Армия заняла Новосибирск, а 19 декабря я был принят на службу в Полевой Контроль 5 Армии заведующим Бюро жалоб. Вслед за Красной Армией, занимавшей Сибирь, я передвигался с Полевым Контролем до Иркутска (начало марта 1920 г.). 8 марта 1920 г. я был принят ячейкой ВКП(б) в партию. 16 марта в составе отряда Полевого Контроля я был направлен в Верхнеудинск для формирования Государственного Контроля образуюшейся Дальне-Восточной Республики (ДВР).

Состоял заведуюшим Общим отделом, а с августа 1920 г. заместителем Государственного Контролера, и в этой должности остался и при пере- 
мещении правительства ДВР в Читу. Здесь по поручению Забайкальского Губкома организовал Политический Суд Забайкальской области и был его председателем до подыскания заместителя, после чего был назначен Членом-докладчиком Кассационного Суда по политическим делам. Принимал участие в выработке Конституции ДВР по судебной части. В июле 1921 г. был назначен заместителем Министра Юстиции (министром был эсер Трупn) с оставлением в Коллегии Госконтроля в качестве сведущчего лища и в должности члена Кассаџионного Суда.

В марте 1922 г. был назначен Полпредом ДВР в Китае и выехал в Пекин, где оставался до ликвидаиии ДВР. В начале декабря 1922 г. назначен Особоуполномоченным СССР в Харбине. По своей просьбе был в сентябре 1923 г. откомандирован в распоряжение Дальбюро ЦК ВКП(б) в Читу и был назначен заместителем начальника ДВ Таможенного округа, а в июле 1924 г. направлен для работы в Государственный Университет во Владивосток.

Здесь работал до 1930 г., преподавая политэкономию, руководя предметной комиссией общественно-политических дисииплин и состоя деканом Восточного факультета. Весь этот период я состоял председателем Бюро Секции научных работников, а с 1926 г. по 1930 г. состоял членом Бюро Партколлектива при Университете, в 1927 г. по поручению Приморского Губкома ВКП(б) был председателем президиума Коллегии защитников, в 1929 г. избран в кандидать Владивостокского Горкома ВКП(б). В этот же период организовал Общество востоковедения и принимал участие в организации других научных обществ, состоял в Президиуме отделения ВОКСА и разных общественных организаций.

В 1930 г. мне было поручено организовать в Хабаровске Институт народного хозяйства, в котором я затем состоял заведуюшим кафедрой политической экономии. На этой работе остался и в Плановом Институте, заменившем собой в 1931 г. Институт Народного Хозяйства и оставался до мая 1933 г., когда Плановый Институт был закрыт. Одновременно, в 1931 г. по поручению Крайкома ВКП(б) реорганизовал Краевой Музей в качестве его директора, и в 1931 г. в июле был назначен организатором Краевой научной библиотеки и Художественного музея, был директором научной библиотеки. Состоял в 1930-1931 г2. членом Хабаровского Горкома ВКП(б). Был председателем Краевого бюро Секции научных работников с 1931 по 1933 г., был членом Президиума Далькрайпреса, членом Совета Отделения Академии наук СССР и участвовал в ряде других общественных организаџий (Общество краеведения, Осоавиахим и др.). По закрытии Планового Института, за отсутствием в Крае других экономических вузов, перешел на работу в ДальКрайплан, но в августе 1933 г., получив приглашение Куйбышевского Планового Института, я с разрешения ДальКрайкома ВКП(б) и по его путевке выехал в г. Куйбышев.

С сентября 1933 г. преподаю в Куйбышевском Плановом Институте историю народного хозяйства и историю экономических учений.

Более подробная автобиография находится в моем личном деле.

В. Погодин» [16, л. 3-4].
Этот документ представляется важным свидетельством эпохи, демонстрирующим, с одной стороны, модус социального поведения, когда подлинным членом советского общества мог считаться только выходец из крестьянской или рабочей среды, а с другой - вариативность встраивания личной истории в этот модус. Василий Львович старается написать текст так, чтобы у читателя автобиографии сложилось представление о том, что автор ничего о себе не скрывает: ни дворянского происхождения, ни службы в царской армии, ни членства в партии эсеров.

Попробуем проанализировать основные линии его изложения.

Обратившись к немногочисленным биографическим справкам об офицере императорской армии Василии Львовиче Погодине, ссылки на которые приведены выше, мы видим, что все они начинаются с констатации факта его социального происхождения: «из дворян». Такой же социальный статус - «сын дворян» - встречаем в краткой характеристике В.Л. Погодина в списке членов профсоюза КПИ [17, л. 39]. Однако в автобиографии акценты проставлены иначе. Погодин в ней манифестирует: «дед - крестьянин», отец - «адвокат». О брате - историке-эмигранте - он не пишет нигде, не упоминает ни в одном документе, с которым нам удалось ознакомиться. Что это: умелое моделирование биографии в эпоху «чисток» и «проработок» или неизвестная нам семейная драма? Скорее, первое. Мы видим в тексте, как, не скрывая в целом дворянства своих предков, он подчеркивает, что дед происходил из крестьян и получил дворянство за военную службу во время войны с Наполеоном, прочно соединившейся в массовом сознании с образами «народной войны» и «крестьянского патриотизма». В действительности, дед Василия Львовича - Александр Васильевич Погодин - был записан во вторую часть Родословной книги дворян Казанской губернии (за военные заслуги) в 1834 г. [18, с. 64].

Сопоставив слова из автобиографии Погодина с визуальными источниками - фотографиями преподавателей и студентов КПИ, преподнесенными в 1936 г. в виде «Альбома к 5-летию КПИ» сотруднику Госплана СССР Н.И. Панину и сохранившимися в архиве Музея истории СГЭУ, - мы замечаем обратную особенность. Внешний вид, манера держаться и сам облик В.Л. Погодина отличаются от остальных преподавателей и студентов и выделяют его из советской крестьянско-пролетарской среды [19]. На фотографии, датированной 1937 г. и подписанной «профессор В.Л. Погодин и доцент В.Ф. Цыба» (рис. 1), Василий Львович Погодин - пожилой интеллигент в костюме-тройке и галстуке, с тростью, трубкой и спичками, зажатыми меж длинных тонких пальцах. Он сидит, изящно сложив ноги, одна на другую, и задумчиво беседует с молодым преподавателем, внимательно слушающим старшего наставника. Дворянские манеры Погодина буквально бросаются в глаза любому смотрящему на эту фотографию. Единственное, что подчеркивает принадлежность Погодина к миру советской визуальности, значок «Ворошиловский стрелок» на лацкане пиджака. Из его автобиографии известно, что еще на Дальнем Востоке он участвовал в работе Общества содействия обороне, авиационному и химическому строительству (Осоавиахим), награждавшего метких стрелков такими нагрудными значками. 


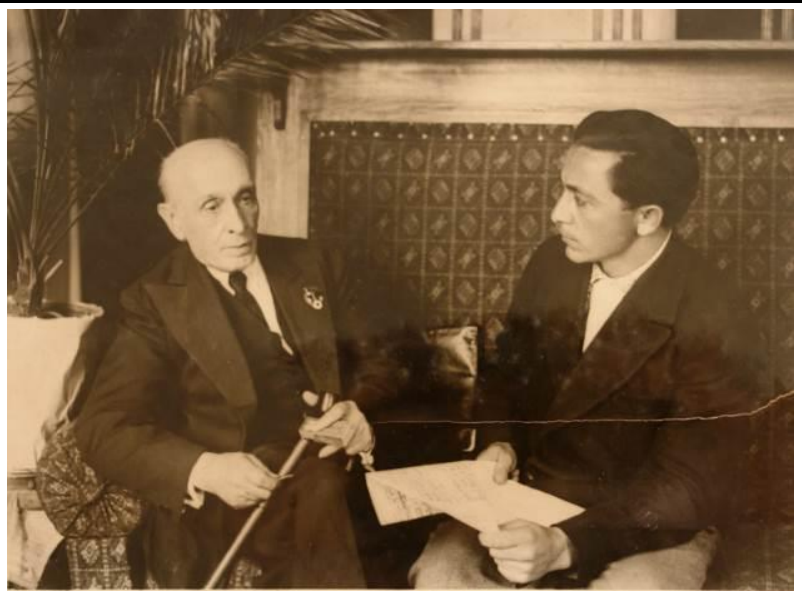

Рисунок 1 - Профессор В.Л. Погодин и доцент В.Ф. Цыба. 1937 г. Архив Музея СГЭУ

Столь же заметно «иное» образование и воспитание Василия Львовича Погодина при чтении стенограмм заседаний ученого совета КПИ, профсоюза работников высшей школы или партийных собраний института, на которых он выступал с пространными и глубокими по содержанию докладами. Его слог, ясный, но выразительный, построение фраз, отсылки к научной и партийной литературе выдавали глубокую гуманитарную эрудицию. В своей анкете он указывал, что его библиотека составляла более 2000 книг по политэкономии, философии, истории и другим наукам. И это в Куйбышеве 1930-х гг., на съемной квартире от института и после переезда из Хабаровска! Конечно, мы не знаем точно, была ли перевезена библиотека В.Л. Погодина из Иркутска в Куйбышев, но полагаем, что могла. Он постоянно следил за выходом в свет новейшей научной и художественной литературы, переводил с французского, немецкого, английского и ряда других европейских языков [20, л. 2 об.].

В автобиографии Василий Львович искусно обходит свою военную карьеру в Российской императорской армии, обратив ее в военно-судебную деятельность, безусловно, очень близкую к действительности. Описывая события 1917 г. и свое участие в них, он подчеркивает близость к «большевистской» линии, указывая, что даже республиканский клуб, созданный с «земцами», т.е. либеральный по своей сути, «объективно способствовал большевизации» армии. Современные оценки армейских процессов позволяют согласиться с этим тезисом и понимать под «большевизацией», в первую очередь, «разложение» армии $[21$, с. 44]. Обращаясь к событиям 1917 г., Погодин подчеркивает свое стремление быть активным участником революционного процесса, свое тогдашнее понимание важности происходивших в стране перемен. Он всячески старается показать, что «союз» с земцами и эсерами в 1917 г. был лишь временным отклонением от верного курса. Дополнительно он указывает на то, что в октябрьские дни, видя неприятие революции эсерами, «рекомендовал партии приветствовать» её. Само построение текста об участии в революции, его логика, последовательность и основные акценты напоминают речь адвоката на суде - В.Л. Погодин будто заранее пытается защититься от нападок своих коллег-большевиков. Вероятно, таковая и была одна из задач, которую он решал, составляя автобиографию: легитимировать своё прошлое, показав себя не «противником» или «попутчиком» революции, а её сторонником и участником. Ведь только это могло примирить его коллег по парткому Куйбышевского планового института образца 1936 г. с дворянским происхождением и офицерским прошлым Погодина. И до лета 1937 г. это работало, они молчали.

Заметно стремление Погодина продемонстрировать преемственность своей деятельности в условиях, как сегодня отмечают некоторые историки, «смутного времени» революции и гражданской войны. В его повествовании нет «цезуры» революции, кардинальной смены власти, изменения лояльности всё это время он «служит»: родине, России, правительству, закону, - как бы ни менялось содержание этих понятий в течение 1917-1919 гг. Особенно выпукло эта «непрерывность» его повествования видна в истории о получении «прогонных денег» по демобилизации, которую он зачем-то подробно излагает в своей краткой автобиографии.

Не менее примечательно то, что он называет крымские власти октября 1918 г. «Временным правительством», снова связывая всю систему власти в единую легитимную последовательность: императорская власть - власть Временного правительства Советская власть. В советской историографии Крым 1918 г. - один из эпицентров Белого движения. Василий Львович умело обходит этот вопрос стороной, подчеркивая, что он работает в военно-судебной системе, как и до демобилизации. Читателю, плохо знакомому с событиями в Бессарабии, в Одессе и в Крыму в 1917-1919 гг., понятно лишь то, что работа В.Л. Погодина была по-прежнему связана с судами, а само его пребывание на юге России вызвано лишь временными объективными обстоятельствами и сложностью возвращения в Иркутск в условиях Гражданской войны.

Восстановив более детально ситуацию на этой территории в 1917-1919 гг., нам станет понятнее выбор Погодина в пользу Иркутска и его решение остаться в Советской России. После Октябрьских событий 1917 г. Южная Бессарабия, на территории которой находился г. Болград (Измаильский уезд Бессарабской губернии в составе Российской империи), оказалась марионеткой в руках нескольких политических сил: молдавских и украинских националистов, румынского правительства, добровольческой армии и советов. После провозглашения Советской власти в октябре 1917 г. фактический главнокомандующий войсками Румынского фронта генерал Д.Г. Щербачев добился непризнания Советской власти фронтовым комитетом, поддержал решение Центральной рады о провозглашении независимости Украинской народной республики (УНР) и об объединении в единый Украинский фронт бывших фронтов русской армии - Румынского и Юго-Западного, возглавив командование им. В ноябре 1917 г. Щербачев наладил связь с войсками добровольческих формирований генерала М.В. Алексеева и начал готовить корпус для отправки его на Дон. Заключенное 26 ноября 1917 г. перемирие в Фокшанах привело к оккупации Южной Бессарабии румынскими войсками в начале января 1918 г.

Начавшиеся в ответ на это военные действия между румынами и советскими войсками закончились в марте 1918 г. поражением румын и подписанием мирного договора в Яссах, по которому Румыния должна была очистить Бессарабию. Однако помощь Германии остановила этот процесс и сохранила Бессарабию в составе Румынии. Одновременно с 
этим австро-германские войска, воспользовавшись сепаратными переговорами с некоторыми представителями УНР, оккупировали территорию Украины, сформировав на ней в апреле 1918 г. прогерманский марионеточный режим гетмана П.П. Скоропадского. Бывшая Румынская армия и сам генерал Щербачев в этих условиях оказывались не у дел, и 18 апреля 1918 г. Щербачев отказался от должности, уехав в имение, предоставленное ему румынским королем.

Исходя из этих обстоятельств понятно, что с конца апреля 1918 г. (как пишет сам В.Л. Погодин, с момента «ликвидации Суда» VI армии) оставаться в Болграде было бессмысленно - фронт развалился окончательно. У Погодина оставался выбор: служить гетману Скоропадскому и его патронам из Германии либо демобилизоваться. Штаб Румынского фронта с января 1918 г. находился в Одессе, и Погодин, судя по сообщению в его автобиографии, отправился к Одесскому военному начальнику, желая получить прогонные деньги для того, чтобы вернуться в Иркутск.

Одесса находилась примерно в 240 км от Болграда и в апреле 1918 г. тоже была под властью гетмана Скоропадского и австро-германского гарнизона. Жизнь в городе была тяжелой, запасы продовольствия вывозились оккупационными войсками, сильно вырос уровень преступности, учреждения оказались в руках украинских националистов. Решив отправиться в октябре 1918 г. в Крым «в поисках работы», Василий Львович правильно рассчитал: он без труда нашел работу в Симферополе, устроившись в военно-судебный отдел Военного ведомства Первого Крымского Краевого правительства и, по всей вероятности, оставался в этой системе и при Втором Краевом правительстве до начала апреля 1919 г. Первое правительство, действовавшее до 15 ноября 1918 г. и возглавляемое генералом М.А. Сулькевичем, опиралось на поддержку Германии и крымских татар, в то время как Второе во главе с С.С. Крымом поддерживалось Белым движением (Добровольческой армией) и состояло из социалистов и либералов, в числе которых были известные кадеты: глава правительства С.С. Крым, министры - В.Д. Набоков, М.М. Винавер и Н.Н. Богданов, председатель земской управы В.А. Оболенский и др. По словам В.А. Оболенского, «эти пять месяцев в Крыму, от ухода немцев до прихода большевиков, можно охарактеризовать как период двоевластия и борьбы двух властей - военной и гражданской» [22, с. 625]. Естественно, оставаться в Симферополе после взятия города войсками Красной Армии В.Л. Погодин не мог и постарался в конце марта - начале апреля 1919 г., когда стало известно, что большевистские войска уже подходят к Перекопу, выехать с Крыма.

Имея возможность отправиться вместе со многими другими офицерами, служившими в Крыму, в эмиграцию на французском или итальянском транспорте, Василий Львович еще прочнее утверждается в решении вернуться в Иркутск. Его перемещения по Сибири летом - осенью 1919 г. показывают, что он вновь оказался на территории, где еще оставались разрозненные белые правительства. Да и получение им второй части прогонных денег в Омске было возможно только в том случае, если местные военные власти считали себя легитимными преемниками прежнего режима. Однако Погодин снова делает выбор в пользу советского режима, оставаясь в Новосибирске до занятия его Красной Армией и переходя на службу к ней.
Педагогическая карьера Погодина началась лишь в 1924 г. - во всяком случае, так он пишет в своей автобиографии. В ней отмечено, что еще до поступления в военное училище в начале 1890 -х гг. он давал частные уроки: видимо, как многие гимназисты, зарабатывал таким образом себе на жизнь. Обращает на себя внимание его ремарка о том, что ещё до революции у него сложилось педагогическое имя в Иркутске. Возможно, этот преподавательский опыт убедил его сменить вид деятельности, отойдя от военной, судебной и дипломатической службы в середине 1920-х гг. Однако колоссальный управленческий опыт, глубокие юридические познания и активная аналитическая деятельность постоянно возвращали В.Л. Погодина к ответственной организационной работе. Он оказался в эпицентре формирования системы высшего образования на Дальнем Востоке, занимая множество ответственных партийных, общественных и управленческих постов: во Владивостоке - декана Восточного факультета университета, председателя Бюро секции научных работников, организатора Общества востоковедов, члена президиума Всесоюзного общества культурной связи с заграницей (ВОКС), в Хабаровске - организатора Института народного хозяйства, директора краевого музея и научной библиотеки, члена горкома партии и пр. В Куйбышеве его жизнь была проще и спокойнее.

О Погодине-преподавателе из документов Куйбышевского планового института и партийной ячейки понятно достаточно многое. Ректор КПИ Я.Л. Коробко, прекрасно знавший, по словам преподавателей, политэкономию, говорил о лекциях Василия Львовича: «они во всех отношениях хороши» [23, л. 17]. Все время преподавания в институте (со 2 сентября 1933 по 10 августа 1937 г.) Погодин считался хорошим лектором. Студенты его ценили. Правда, по словам председателя месткома, «авторитет Погодина в среде студентов являлся результатом либерального отношения к студентам при оценке» $[23$, л. 3]. Вероятно, В.Л. Погодин действительно был «лоялен» к студентам, но лишь в том смысле, в каком стремился сделать обучение более эффективным и понятным. В частности, в практических занятиях он видел возможность преодолеть разрыв между лекцией и самостоятельной работой, а во введении исторических элементов в лекции по политэкономии - способ оживить материал [24, л. 2, 47]. Вольномыслием, по мнению коллег, звучали его слова о том, что «только высоко качественная лекция может обеспечить достаточное количество консультирующихся» студентов [24, л. 48]. Мало кто из них соглашался с тем, что только интересная и понятная лекция может побудить студентов включиться в её обсуждение и начать задавать вопросы преподавателю.

Он был одним из самых квалифицированных преподавателей Куйбышевского планового института, занимался не только исследованиями в области экономики, но и методикой преподавания в вузе [17, л. 39]. Из архивных документов известно, что его статья «Анализ товара в 1-м издании «Капитала» Маркса в отличие от 2-го издания» должна была войти в издание трудов КПИ [25, л. 147]. Однако ни в первом, ни во втором томе ученых записок КПИ мы её не обнаружили. Другая его статья «Методика преподавания политэкономии», опубликованная в «Бюллетене Госплана», была посвящена возможностям применения практических занятий в гуманитарных дисциплинах, хотя большинство преподава- 
телей КПИ отказалось от практических занятий [24, л. 2]. Тематический план научно-исследовательской работы В.Л. Погодина в 1935 г. включал изучение тем: «Первоначальные накопления в России», «Историческое место азиатского способа», а также рецензию на только вышедшую «Историю политической экономии» Д.И. Розенберга [25, л. 148]. Все это демонстрирует активную исследовательскую работу Погодина.

Дадим еще раз слово В.Л. Погодину, приведя фрагмент из его доклада «О содержании семинаров», прочитанного на заседании Совета КПИ 31 марта 1936 г.:

«Я принадлежу к числу критиков методов преподавания, существующих в наших вузах, основываясь 6 этом на двух документах, которые не соответствуют, по моему глубокому убеждению, принятым у нас методам преподавания - постановлений ЦК $и$ СНК от 19.09.1932 г. о реформе высшей школь и постановлении комитета о выстей школе от августа 1934 г. < ..> Все методы преподавания в своей совокупности должны обеспечить самостоятельную, индивидуальную работу студентов. Mbl должнь осуществить дифференцированный подход к каждой самостоятельной, индивидуальной работе студентов, а не проводить работу вообще. Полностью осуществить требования закона о дифференцированном подходе [к отличникам и отстающим - прим. авт.] мы не можем, но что-то делать должны. <...> У нас семинар не является той стадией самостоятельной работь, по которой студент получает навыки, известную постановку в работе, чтобы самого себя проверить <..> эта самостоятельная работа заканчивается только оченкой, и студент должен продолжать работать по той же самой теме, которая проработана на семинаре. А на следуюший день опять два урока. И в коние конџов вместо индивидуальной самостоятельной работы получается, что студент по клочкам изучает дисииплину, ничего не может связать, ничего не получает общего, не получает метода работы. В результате мы за деревьями не видим леса. Разве это нама задача? Наша задача, как говорится в Постановлении ЦК, - глубокое знание по специиальности и иирокий общественно-политический горизонт. А вот изучая по клочкам полит. экономию, диамат и пр. в коние года обнаруживается полная неграмотность студентов. Студент не может связать кониы с кониами, не может дать ответа на самые простые вопросы, потому что он изучал по кусочкам, по клочкам, на зачетах это очень часто обнаруживается, на зачетах мы видим, что студент не смог овладеть методом получения знаний и мы в этом отношении плетемся в хвосте» [26, л. 81-82].

Как видим, он занимал ярко выраженную критическую позицию по отношению к организации и эффективности учебного процесса и мог аргументированно и научно её изложить, - качество, присущее далеко не каждому преподавателю высшей школы 1930-х гг

Одновременно с преподаванием и научной работой, В.Л. Погодин, судя по документам, занимался в институте активной общественной деятельностью. В 1934 г. он входил в состав редколлегии «Ученых записок» КПИ, был членом Совета института [4, л. 105]. Будучи членом партии с 1920 г., он вел ак- тивную партийную жизнь: состоял консультантом при парткоме института, являлся председателем Ревизионной комиссии при месткоме и был пропагандистом партийного кружка Истории ВКП(б) Планового института [20, л. 2]. Высокой была и оплата труда В.Л. Погодина: его оклад при 440 ч. в год составлял 700 руб. (выше был только оклад профессора философии Дулова - 920 руб.), в то время как оклады доцентов колебались при нагрузке от 380 до 500 ч. в диапазоне от 310 до 400 руб. [4, л. 22].

Безусловно, авторитет Погодина в партийной ячейке института был велик до тех пор, пока в 1937 году не начались новые «чистки». Его партийная деятельность на Дальнем Востоке и в Китае, долгое членство в ВКП(б) многое должны были говорить о его статусе в партии. Однако после «чистки» 1933 г., а потом и 1937 г. состав местных партийных организаций изменился. В них появилось много молодых, желающих сделать карьеру активистов, выходцев из комсомольской среды. Для них Погодин социальный враг, представитель старого, отжившего мира, а заодно и носитель статуса, который эта молодежь жаждет присвоить себе.

Любопытно, что в первых прениях парткома КПИ по поводу Погодина, во всей обрушившейся на него критике и обвинениях в лояльности к так называемым «правым», прозвучавшей в лекции (Бухарину и др.), ни разу не упоминалось о его социальном происхождении из дворян, а также его членстве в партии эсеров в 1917 году, пока эти разговоры не начались в профсоюзе и горкоме. Погодина вообще долго «не трогали». Партийные «чистки», начавшиеся в институте в 1933 г., «вымыли» первый состав администрации и преподавателей вуза: были осуждены и репрессированы ректор КПИ З.Б. Ливянт, профессора Г.И. Баскин, Г.С. Франкфурт и др. В 1936-1937 гг. прокатилась новая волна так называемых «разоблачений» и арестов, но партком КПИ и в этот раз будто не знал о прошлом Погодина. И даже во время первого разбирательства «дела Погодина», как видно из протоколов парткома института, критиковали его относительно слабо. Его обвиняли лишь во «вредительстве», в то время как В.А. Фаддеев (заместитель директора по учебной и научной работе), Т.И. Алымов (и.о. доцента кафедры экономики и техники сельского хозяйства) и А.А. Пуреховский (зав. кафедрой политической экономии) за пару месяцев до этого были заклеймены «врагами народа» [23, л. 1-2].

Спусковым крючком «дела» В.Л. Погодина стали, как ни странно, вовсе не его происхождение, эсеровское прошлое и «либеральные» лекции, а случайные события, происшедшие с Погодиным в поезде при возвращении из Ленинграда в ночь на 1 августа 1937 г., результатом которых стала пропажа его партийного билета. Обстоятельства этой ночи хороши известны из письменного заявления, которое Погодин сделал в партком 4 августа, а также из выступления на заседании парткома по этому вопросу 8 августа 1937 г. [27, л. 32-35]. Поразительно быстро разворачиваются события перед читающим эти документы. За один день Погодин превращается из одного из самых авторитетных членов парткома (его имя обычно первое в списке, отзываются о нем неизменно уважительно, его отправляют на партийные конференции от института, включают в ревизионные комиссии и т.п.) в «очковтирателя», либерала- 
«примиренца», «мягкотелого» симулянта из «бывших».

Из предшествовавших заседаний парткома мы видим, как весной 1937 г. в организации усиливается подозрительность к преподавателям и запускается программа поиска среди них «укрывшихся» врагов. Даже активисты парткома и месткома оказывались под подозрением и «прорабатывались» каждую неделю на партийных собраниях, открытых и закрытых. В сентябре 1937 началось наступление на ректора Я.Л. Коробко, закончившееся его увольнением. Как и во многих других советских организациях этого времени, найденный «вредитель» оказывался самым подходящим объяснением всех ошибок и недочетов, возникавших у администрации. Под подозрение в «пособничестве», скрытых связях с «врагами» попадали практически все преподаватели-коммунисты, деятельность которых была мало-мальски «идейной» и активной. Спустя полгода один из сотрудников Госплана, проверявших деятельность института, даже заявил на заседании парткома о том, что все «разборы» преподавателей и «чистки», через которые КПИ прошел с марта по ноябрь 1937 г. даже на фоне других институтов выглядят «перебором»: сначала партком «врагов» не видел, а потом оказалось, что «враги» почти все [28]. Василий Львович попал в этот «молох».

Начавшаяся в августе 1937 г. травля Погодина сопровождалась публичным осуждением его так называемых «либеральных извращений» и закончилась увольнением Василия Львовича 10 августа 1937 г. Причинами увольнения были, по словам директора института Я.Л. Коробко, «отсутствие политической заострённости в лекциях, примиренческое отношение к критике правых, «сомнительный» объективизм» [29, л. 39]. Воспользовавшись историей с потерей партийного билета, коллеги обвинили Погодина в преступной халатности и даже симуляции пропажи документов, заявив о том, что «разбирали» бы В.Л. Погодина и без истории с партбилетом, т.к. основанием для обвинений стала стенограмма лекции Погодина, по мнению парткома, ясно демонстрировавшая его партийные «ошибки».

Заявив о «неправильном увольнении из института», Погодин обратился в президиум Куйбышевского обкома Союза высшей школы и научных работников с просьбой пересмотреть решение парткома института. Однако на заседании президиума бывшие коллеги заклеймили его еще резче: «В лекции не было партийности, что является достаточным для увольнения. Большевистской заостренности нет. В выступлениях Погодина отсутствует самокритика», - заявлял один из членов обкома профсоюза; «Высоко-идейного материала не дано, а есть примиренческое отношение к врагам народа», - говорил председатель месткома КПИ, как и Погодин читавший курс политэкономии [29, л. 39]. «Уж кто, а Погодин нам всем втер очки, общая направленность лекций была смазать сущность врагов народа», - получил возможность высказаться на закрытом заседании партсобрания КПИ 8 сентября 1937 г. бывший студент В.Л. Погодина, секретарь парткома [23, л. 22]. «Что Погодин - враг, оснований нет, но что он с кафедры преподносил не то, что нужно - факт», - заключал он [23, л. 23].

Рекомендация президиума обкома профсоюза жестко начиналась со слов о том, что увольнение его не только следует признать правильным, но и уже- сточить его основание, уволив по ст. 47 «в» КЗОТ, т.е. из-за «обнаружившейся непригодности нанявшегося работника» [30]. Это означало на практике, что В.Л. Погодина увольняли без прав на выходное пособие, лишив не только заработной платы, но и квартиры, которая предоставлялась ему институтом, а также возможности устроиться в другой вуз. Несложно представить дальнейшую судьбу 67-летнего профессора, выходца из дворян, в Куйбышеве 1937 года. Сумел ли он уехать из города, или нашел возможность устроиться на работу где-нибудь еще, пока не известно.

Таким образом, судьба Василия Львовича Погодина показывает неординарный характер его личности: будучи генерал-майором армии Российской империи и сделав блестящую военную карьеру в годы поздней Российской империи, он сумел встроиться в новую советскую систему, кардинально поменяв сферу своей деятельности и добившись не менее выдающихся результатов, став полномочным представителем Дальневосточной Республики в Китае, директором нескольких учебных и культурных учреждений Дальневосточного края, а затем профессором политэкономии Куйбышевского планового института. Жизненный путь В.Л. Погодина показывает коллизии человеческого поведения в переломные моменты истории, когда обнажаются сущностные черты человеческой личности. Приведенные материалы являются хорошей почвой для изучения опыта распространения государственного социального проекта по внедрению марксистского мировоззрения в систему высшего образования советской страны. Жизнь Погодина показывает, что этот проект был не только смелым социальным экспериментом, но и трагичным одновременно.

Автор приносит искреннюю благодарность за помощь в работе с документами ЦГАСО Гальгиной Галине Валентиновне и Фроловой Кире Владимировне. Материаль из фондов РГАСПИ были любезно предоставлены Татьяной Александровной Орнацкой (2. Хабаровск), за что автор чрезвычайно признателен. Автор также благодарит за поддержку и помощьь в работе с архивными документами Музея СГЭУ его директора - Солдатову Ольгу Евгеньевну. Публикаиия автобиографии В.Л. Погодина из фондов СОГАСПИ была бы невозможна без помощи Удинцева Андрея Германовича и Малинкина Евгения Михайловича.

\section{Список литературы:}

1. Перес К. Технологические революции и финансовый капитал: динамика пузырей и периодов процветания / пер. с англ. Ф.В. Маевского, науч. ред. пер. С.Ю. Глазьев, В.Е. Дементьев. М.: Дело, 2011. $231 \mathrm{c}$.

2. Тагирова Н.Ф., Солдатова О.Е. Интеграционные и дезинтеграционные процессы в экономике Самарского региона на фоне политической истории XX в. // Вестник Самарского государственного экономического университета. 2014. № 11 (121). С. 2835.

3. Суходолов А.П., Майдачевский Д.Я. Экономическое образование России и региона: ответ на модернизационные вызовы середины XX века // Известия Байкальского государственного университета. 2017. Т. 27, № 2. С. 123-130.

4. Центральный государственный архив Самарской области (ЦГАСО). Ф. Р-3572. Оп. 1. Д. 44. 
5. Очерки истории Самарского государственного экономического университета (к 85-летию со дня образования) / отв. ред. Г.Р. Хасаев, Н.Ф. Тагирова. Самара: Изд-во Самар. гос. экон. ун-та, 2016. 388 с.

6. Погодин Василий Львович [Электронный ресурс] // Русская армия в Первой мировой войне / А. Лихотворик. - http://grwar.ru/persons/persons.html?id=5120.

7. Погодин Василий Львович [Электронный ресурс] // Офицеры РИА. - http://ria1914.info/index.php?title= Погодин_Василий_Львович.

8. Крымская книга памяти Великой войны 19141918 гг. Приложение к I тому / сост. А.И. Григоров. [Б.м.], 2012-2014. 163 с.

9. Казанское дворянство, 1785-1917 гг.: Генеалогический словарь / сост. Г.А. Двоеносова. Казань: Приложение к журналу «Гасырлар авазы - Эхо веков», 2001. 639 с.

10. Российский государственный архив социально-политической истории (РГАСПИ). Ф. 372. Оп. 1. Д. 565.

11. Орнацкая Т.А., Ципкин Ю.Н. Отношения Дальневосточной республики с Китаем (1920-1922 гг.) // Россия и АТР. 2007. № 3. С. 17-26.

12. Логинов М.А., Григорьева Е.А. Эволюция политики большевиков в отношении КВЖД в первые годы власти (1917-1925) // Политическая культура и международные отношения в новое и новейшее время: сб. науч. трудов / под ред. М.В. Белова. Нижний Новгород: Изд-во ННГУ, 2009. С. 75-89.

13. Васильева Е.В. О мировоззрении дальневосточных ученых первой половины XX века // Вестник ДВО РАН. 2005. № 5. С. 98-118.

14. Малявина Л.С. В условиях «необъявленной войны». Особенности развития образовательной системы советского Дальнего Востока в 1930-е годы // Социальные и гуманитарные науки на Дальнем Востоке. 2015. № 3 (47). С. 175-181.

15. Лаптева Л.П. Русский историк-славист Александр Львович Погодин: Жизнь и творчество (1872-
1947). М.: Дом русского зарубежья им. А.И. Солженицына, 2011. 147 с.

16. Самарский областной государственный архив социально-политической истории (СОГАСПИ). Ф. 1004. Оп. 19. Д. 4.

17. СОГАСПИ. Ф. 9004. ОП. 1. Д. 9.

18. Алфавитный список родоначальникам потомственных дворян, внесенных в дворянскую родословную книгу Казанской губернии с 1787 по 1895 г.: сост. по 1-е нояб. 1895 г. Казань: Скоропеч. Л.П. Антонова, 1896. 100 с.

19. Архив Музея СГЭУ. Альбом к 5-леттю КПИ (1936 г.).

20. СОГАСПИ. Ф. 1004. Оп. 19. Д. 48.

21. Асташов А.Б. Моральный дух и настроения русской армии в Первой мировой войне // От противостояния идеологий к служению идеалам: российское общество в 1914-1945 гг.: сб. ст. / под ред. М.Ю. Мягкова, К.А. Пахалюка. М.: Новый хронограф, 2016. С. 33-46.

22. Оболенский В.А. Моя жизнь и мои современники. Париж: YMCA-Press, 1988. 754 c.

23. СОГАСПИ. Ф. 656. ОП. 28. Д. 223.

24. СОГАСПИ. Ф. 9530. Оп. 1. Д. 6.

25. ЦГАСО. Ф. Р-3572. ОП. 1. Д. 93.

26. ЦГАСО. Ф. Р-3572. Оп. 1. Д. 75.

27. СОГАСПИ. Ф. 583. ОП. 2. Д. 9.

28. СОГАСПИ. Ф. 583. ОП. 2. Д. 96.

29. СОГАСПИ. Ф. 9530. Оп. 1. Д. 2.

30. Кодекс законов о труде РСФСР. Закон от 31 декабря 1922 г. // Собрание Узаконений и Распоряжений Рабочего и Крестьянского Правительства РСФСР. 1922. № 70. Ст. 903.

Исследование выполнено при финансовой поддержке РФФИ и Правительства Самарской области в рамках научного проекта № 18-49-630008 "Oпыт социального проектирования в сфере высшего экономического образования Самарского края первой половины $Х X$ в.».

\title{
PROFESSOR OF THE KUIBYSHEV PLANNING INSTITUTE VASILY LVOVICH POGODIN: MATERIALS FOR THE BIOGRAPHY
}

(C) 2019

\author{
Zherdeva Yulia Aleksandrovna, candidate of historical sciences, \\ associate professor of Institutional Economics and Economic History Department \\ Samara State University of Economics (Samara, Russian Federation)
}

Abstract. The paper is based on archival materials about the activities of the Kuibyshev Planning Institute of the 1930s. It reconstructs the biography of the Russian and Soviet diplomat, military and academic of the first third of the $20^{\text {th }}$ century, Vasily Lvovich Pogodin (1870 - after 1937). The study reveals a set of documentary evidence on the diplomatic and pedagogical career of V. Pogodin in the first years of the Soviet power, and determines the features of his pedagogical and party activities in Kuibyshev in 1933-1937. The author highlights a special role of the Planning Institute party committee materials as well as the high school workers trade union in the reconstruction of Pogodin's biography. The paper emphasizes that Pogodin was considered to be one of the best lecturers of the Kuibyshev Planning Institute and a credible party worker. It is noted that his noble origin, service in the tsarist army and membership in the party of the Social Revolutionaries until 1937 were not the reason for penalties or prosecution by the party or the university administration. As a result, the author concludes that the fate of Vasily Lvovich Pogodin shows an extraordinary character of his personality. He made a brilliant military career in the years of the late Russian empire and became a major general of the Russian imperial army. Then he managed to integrate into the new Soviet system, radically changing the sphere of his activity and having achieved no less outstanding results in diplomacy and education. He became the plenipotentiary representative of the Far Eastern Republic in China, the director of a number of educational and cultural institutions of the Far East, then a professor of political economy in Kuibyshev.

Keywords: Kuibyshev; 1930s; economy; economic Education; educational institution; planning institute; Marxism; teaching techniques; Vasily Lvovich Pogodin; Alexander Lvovich Pogodin; nobility; officers; World War I; history of national economy; political economy; repression; party purge. 